\title{
Reasoning Research on Financial Performance of Listed Companies After Asset Reorganization Based on Business Integration
}

\author{
Yipa Dong ${ }^{1, *}$ \\ ${ }^{1}$ College of Business and Economics, The Australian National University, Canberra, ACT 2600, Australia \\ "Corresponding author.Email:dyp_1003@163.com
}

\begin{abstract}
This paper takes Midea Group's absorption and merger of Little Swan through share swaps as an analysis case, and analyzes the financial performance of public firms in the household appliance industry before and after mergers and acquisitions based on accounting research methods. This paper collects the traditional financial indicators of the public firm in the last five years and one quarter, and examines performance in terms of financial status, profitability, capital structure and solvency. From the perspective of financial status, Midea Group's assets and sales scale have been expanding year by year, and there are few idle funds because of active investing and financing activities. Although the main products have a relatively high market share, they have not taken full advantage of the acquired company, Little Swan, in the washing machine field. Mergers and acquisitions have little impact on the profitability of companies. Since the year of mergers and acquisitions, the increase in gross profit has decreased, and the impact of scale expansion on the marginal returns of commodities can be considered. From the perspective of current ratio, quick ratio, and cash ratio, mergers and acquisitions have a positive impact on the company's solvency.
\end{abstract}

Keywords: Financial Performance, Major Asset Reorganization, Business Integration

\section{INTRODUCTION}

Although China's capital market has become increasingly large-scale and deepened, it has only developed for a few decades. We are often amazed at which company is listed on NASDAQ or on the Hong Kong Stock Exchange, but it is not common to see mergers and acquisitions and reorganizations being widely publicized. However, the mainstream melody of the global capital market every year is still mergers and acquisitions. The transaction volume is much higher than the IPO financing amount.

At the beginning of 2020, the outbreak of Covid-19 put many industries in a "closed" state and brought many small- and medium-sized enterprises to the brink of extinction. Many entrepreneurs are facing a serious problem: what if the original rhythm is disrupted and there is no hope of financing? In fact, mergers and acquisitions may be a good choice at this time. In the face of severe crisis, timely stop loss and self-help is the adoptable way, and companies should "always leave a window for mergers and acquisitions."
The epidemic has become a catalyst for the M\&A market. In terms of capital, the tendency to buyout strategies adopted by emergence of super unicorn companies and the later PE institutions is giving birth to a new generation of buyers other than Internet giants; in terms of asset, the epidemic puts pressure on the corporate performance, and it increases the firm's willingness to be valued and sold. There are many buyers to participate in the capital market because of these changes caused by Covid-19. In 2020, China's capital market ushered in a wave of mergers and acquisitions.

\section{LITERATURE REVIEW}

\subsection{Asset Reorganization}

Horizontal mergers and acquisitions are an effective way for companies to reallocate resources, expand market shares, and achieve economies of scale in the same industry. Capron (1999) finds that the resources reorganization of both parties in horizontal mergers and acquisitions can improve revenue-enhancing capabilities. [1] Maksimovic, Phillips and Yang (2013), Arikan and Stulz (2016) point out that private firms that tend to go 
public increase productivity and expand their size through mergers and acquisitions. [2] [3] Yanhua (2019) analyzes that horizontal mergers and acquisitions as a strategy can promote the realization of economies of scale and synergies, which can not only control investment costs and merger risks, but also reduce vicious competition and drawbacks in commercial competition. [4] Zhao (2020) and Cai (2020) focus on China's household appliance industry. Zhao (2020) proposes that overseas mergers and acquisitions are one of the ways for firms to quickly enter the international market. The acquirer can reduce trade barriers, expand overseas markets and increase market share; Meanwhile, the target firm can also reduce production costs and increase profitability. Both parties can ultimately achieve technology sharing and talent sharing, which can enhance the core strength of the company's long-term development and strengthen its competitive advantage. [5] Cai (2020) also proposes that successful mergers and acquisitions completed by reasonable payment method, controlled merger premiums and efficient integration of advantageous resources can achieve technology sharing, equipment sharing, and sales and purchase channel sharing, eventually achieve synergies, increase market share, and enhance brand influence and industry competitiveness, and form a mutually beneficial situation for the merger and acquisition parties. [6]

\subsection{Financial Performance Research}

Feng and Wu (2001) used China's listed M\&A cases from 1994 to 1998 as sample data, and used financial indicators to construct a comprehensive score to measure the performance before and after M\&A. Through empirical analysis, they show that horizontal M\&A of listed companies are more likely to integrate target companies and achieve economies of scale. Although the performance does not improve significantly in the first year after M\&A, it shows an upward trend. By the third year after M\&A, horizontal M\&A outperforms vertical and mixed M\&A. [7] Zhang (2003) used the event research method based on stock price changes and the accounting research method based on financial indicators to conduct an empirical analysis on the performance of the merger and reorganization events of listed companies in China from 1993 to 2002. Zhang (2003) concludes that performance of target firms can be improved in the shortterm after M\&A, but it lacks continuity in the long-term, while acquirers may suffer a certain negative impact. However, this research has the limitations of the limited sample of acquirers and difficulty in analysing the combined effects. [8] Liu and Wang (2020) put forward the opposite conclusion to Feng and $\mathrm{Wu}$ (2001). They adopted accounting research methods, based on the sample data of M\&A of public firms in China from 2014 to 2016, and used factor analysis to calculate the comprehensiveness of the enterprise from the four aspects of solvency, profitability, operation and development capabilities. They find that the performance of horizontal mergers in the current year is lower than the previous year. Although the performance of the two years after mergers can be improved, it is still lower than that before mergers. Mergers and acquisitions are not conducive to improving corporate performance because of excessive integration costs. [9] Zeng and Cao (2020) conducted a case study of mergers and acquisitions. They used a typical case of horizontal mergers and acquisitions in the furniture manufacturing industry in 2012 as a sample. Based on traditional financial indicators, they analyzed the performance of post-merger companies from the four aspects of solvency, profitability, operation and development capabilities. Moreover, they used the economic value added (EVA) method to measure M\&A performance. They reveal that M\&A has negative impact on firm's solvency due to cash payment methods, while has positive impact on firm's profitability, operation and development capabilities. And the economic value added (EVA) has an upward trend in the two years after M\&A. However, this study is only based on the furniture manufacturing industry with low industrial concentration, and its conclusions may not be applicable to other industries. As well as, the EVA calculation is based on multiple adjusted financial data and capital market risk coefficients, and its calculation results may be distorted. [10] Almost contemporaneously, Liu (2020) used the M\&A case occurred in 2018 in the pharmaceutical industry, and based on financial indicators, analyzed the performance before and after the asset restructuring from the four aspects of solvency, profitability, operating capacity and cash flow. Liu (2020) shows that the shortterm debt solvency of pharmaceutical companies becomes weaker after the asset reorganization, and the increase in sales expenses causes the company's core profit margin to drop significantly, and the overall valueadded capacity of operating assets cannot be improved. However, the asset turnover rate in operations can be increased because of the expanded sales channels. As for cash flow, the company's ability to create cash based on its own resources is weakened after reorganization. The limitations of this analysis case are obvious features and limited adaptability. [11]

In previous studies, some scholars used a large sample size as the research point, combined with market analysis methods and financial analysis methods to study performance before and after mergers and acquisitions. Based on sample data at different stages, the conclusions drawn from the existing literature are different. In addition, only a small amount of research is based on a typical case, and there are limitations of obvious industry and case characteristics. An entire research system combining point and sphere has not yet been formed. Since China's capital market is still weak-form efficient, this paper takes Midea Group's absorption and merger of Little Swan through share swaps as an analysis case, and analyses the financial performance of public firms in the 
household appliance industry before and after mergers and acquisitions based on accounting research methods.

\section{INTRODUCTION OF M\&A PARTIES}

Midea Group Co., Ltd., the acquirer, was established on April 7, 2000 and was listed on the Shenzhen Stock Exchange on September 18, 2013. As of the end of the third quarter of 2018, its registered capital reached RMB 6.645 billion. Midea Group is in a leading position in the electrical machinery and equipment manufacturing industry. Its main business focuses on the research and development of HVAC, consumer appliances, robots and automation systems, and intelligent supply chain (logistics). The main products involve air conditioning, heating and ventilation systems, various large and small household appliances, robots and automation systems, and Annto's logistics platform, etc. Before this M\&A, Midea Group had made a cash offer to acquire shares of KUKA Group through its wholly-owned overseas subsidiary MECCA International (BVI) Limited in 2016. Henceforth, Midea Group has held a total of $94.55 \%$ of KUKA Group's shares, and has further expanded its overseas sales channels.

The acquired party, Wuxi Little Swan Co., Ltd., was established on November 29, 1993. It was listed on the Shenzhen Stock Exchange in July 1996, with an initial public offering of B shares, and in March 1997, an initial public offering of A shares. Its registered capital is RMB 632 million. And its production and sales are mainly washing machines and dryers. Its annual production capacity exceeds 24 million units. There is a R\&D team of more than 900 people, a national-level enterprise technology center and two nationally recognized laboratories. As a result of optimizing product structure, developing e-commerce sales channels, and expanding overseas markets, Little Swan achieved operating income of RMB 21.385 billion in 2017, gross margin reached $25.26 \%$, and sales volume increased by $18.37 \%$ year-onyear, which was higher than the industry average.

\section{FINANCIAL PERFORMANCE ANALYSIS}

\subsection{Financial Status}

\subsection{1. $\quad$ Assets and Liabilities}

Table 1. Midea Group's Assets and Liabilities at the End of Each Year from 2015 to 2019 and the End of the Third Quarter of 2020

unit: RMB million

\begin{tabular}{lcccccc}
\hline \multicolumn{1}{c}{ Year } & $2020-09-30$ & $2019-12-31$ & $2018-12-31$ & $2017-12-31$ & $2016-12-31$ & $2015-12-31$ \\
\hline Total Current Assets & $245,480.99$ & $216,482.69$ & $182,689.44$ & $169,810.68$ & $120,621.32$ & $93,367.71$ \\
Total Non-current Assets & $104,962.46$ & $85,472.73$ & $81,011.71$ & $78,296.18$ & $49,979.39$ & $35,474.23$ \\
Total Assets & $350,443.45$ & $301,955.42$ & $263,701.15$ & $248,106.86$ & $170,600.71$ & $128,841.93$ \\
Total Current Liabilities & $184,335.74$ & $144,318.48$ & $130,231.09$ & $119,091.86$ & $89,184.00$ & $72,003.85$ \\
Total Non-current Liabilities & $45,978.71$ & $50,140.84$ & $41,015.54$ & $46,089.83$ & $12,440.01$ & 806.46 \\
Total Liabilities & $230,314.46$ & $194,459.32$ & $171,246.63$ & $165,181.69$ & $101,624.01$ & $72,810.31$ \\
Total Equities & $120,128.99$ & $107,496.10$ & $92,454.52$ & $82,925.17$ & $68,976.70$ & $56,031.62$ \\
\hline
\end{tabular}

From Table 1, Midea Group's assets scale has been expanding year by year and has exceeded 300 billion yuan at the end of 2019. At the end of the third quarter of 2020, the total assets reached RMB 350.443 billion, of which current assets accounted for $70.05 \%$. The proportion of current assets is approximately equal to that at the end of each year. At the end of the third quarter of 2020, total liabilities reached RMB 230.314 billion, accounting for $65.72 \%$ of total assets. This ratio was approximately $58 \%$ at the end of 2015 and 2016, and remained at around $65 \%$ at the end of 2017-2019 and the end of the third quarter of 2020. The proportion of current liabilities to total liabilities was as high as $98.89 \%$ at the end of 2015 . At the end of 2017 , it was $72.1 \%$ that is the smallest among the six-time nodes. And at the end of the third quarter of 2020 , it reached $80.04 \%$. In addition, the scale of owner's equity has been increasing year by year. At the end of 2015, it was only RMB 56.03 billion, and reached RMB 120.129 billion at the end of the third quarter of 2020 . 


\subsubsection{Profit}

Table 2. Midea Group's Profit in Each Year from 2015 to 2019 and the First Three Quarters of 2020

unit: RMB million

\begin{tabular}{lcccccc}
\hline \multicolumn{1}{c}{ Year } & $2020-09-30$ & $2019-12-31$ & $2018-12-31$ & $2017-12-31$ & $2016-12-31$ & $2015-12-31$ \\
\hline Operating Income & $216,760.79$ & $278,216.02$ & $259,664.82$ & $240,712.30$ & $159,044.04$ & $138,441.23$ \\
Operating Costs & $161,943.46$ & $197,913.93$ & $188,164.56$ & $180,460.55$ & $115,615.44$ & $102,662.82$ \\
Gross Profit & $54,817.33$ & $80,302.09$ & $71,500.26$ & $60,251.75$ & $43,428.60$ & $35,778.41$ \\
Operating Profit & $25,875.96$ & $29,683.09$ & $25,564.11$ & $21,627.85$ & $17,435.97$ & $14,916.87$ \\
Net Profit & $22,194.00$ & $25,277.14$ & $21,650.42$ & $18,611.19$ & $15,861.91$ & $13,624.66$ \\
\hline
\end{tabular}

Table 2 shows that the corporate's sales scale continues to expand. In the first three quarters of 2020, the company achieved operating income of 216.76 billion yuan, operating costs of 161.943 billion yuan, gross profit, operating profit and net profit of 54.817 billion yuan, 25.876 billion yuan, and 22.194 billion yuan, respectively. Although the gross profit has increased year by year from 2015 to 2019 , one year after the completion of the M\&A (hereinafter referred to as 2019), the annual increase in operating income was basically the same as that in the year of the M\&A (hereinafter referred to as 2018), while the annual increase in operating costs was relatively large. Therefore, the increase in corporate gross profit declined. Although the sales scale has been increasing year by year, its growth rate has dropped significantly since the year of the M\&A. It may be caused by the diminishing marginal productivity of input factors. Moreover, the gross profit in the first three quarters of 2020 is much lower than the gross profit for the whole year of 2019, even less than the gross profit for the whole year of 2017. The impact of mergers and acquisitions on the marginal benefit of products should be fully considered. The annual growth rate of operating profit and net profit has not shown a slowing trend, and operating profit and net profit in the first three quarters of 2020 have exceeded the whole year of 2018, which is not greatly affected by M\&A.

\subsubsection{Cash Flow}

Table 3. Midea Group's Cash Flow in Each Year from 2015 to 2019 and The First Three Quarters of 2020

unit: RMB million

\begin{tabular}{|c|c|c|c|c|c|c|}
\hline Year & $\begin{array}{l}2020-09- \\
30\end{array}$ & $\begin{array}{l}2019-12- \\
31\end{array}$ & $\begin{array}{l}2018-12- \\
31\end{array}$ & $\begin{array}{l}\text { 2017-12- } \\
31\end{array}$ & $\begin{array}{l}2016-12- \\
31\end{array}$ & $\begin{array}{l}\text { 2015-12- } \\
31\end{array}$ \\
\hline $\begin{array}{l}\text { Net cash flow from operating } \\
\text { activities }\end{array}$ & $25,014.63$ & $38,590.40$ & $27,861.08$ & $24,442.62$ & $26,695.01$ & $26,764.25$ \\
\hline $\begin{array}{l}\text { Net cash flows from investing } \\
\text { activities }\end{array}$ & $32,098.58$ & $23,107.70$ & $18,642.29$ & $\begin{array}{c}- \\
34,739.61\end{array}$ & $19,781.08$ & - \\
\hline $\begin{array}{l}\text { Net cash flow from financing } \\
\text { activities }\end{array}$ & $8,101.38$ & $-3,273.60$ & $\begin{array}{c}- \\
13,387.16\end{array}$ & $19,651.65$ & 159.91 & $-8,876.65$ \\
\hline
\end{tabular}

From Table 3, the investment scale of enterprises has been at a relatively high level since 2015 , and idle funds are small. Especially in 2017 and 2020, the net cash outflow used by enterprises for investment activities has exceeded 32 billion yuan, and the funding gap has been filled through financing activities. In 2017, due to the development of overseas business, e-commerce channels and smart household appliances, Midea Group had large 
investment and financing activities. The total net cash flow of the merger and acquisition year was negative. The company expanded significantly, capital was tight, and debt repayment pressure was high. One year after the completion of the merger, due to the high recovery efficiency of accounts receivable, the net cash flow from operating activities is more than 10 billion yuan higher than other years in the past five years, reaching 38.59 billion yuan. In the first three quarters of 2020, due to continued expansion and increased investment after corporate mergers and acquisitions, the net cash flow generated by the company's investment activities and financing activities was -32.099 billion yuan and 8.101 billion yuan respectively. Compared with other years, investment and financing activities are more active.

\subsubsection{Composition of Operating Income and Market Share}

\subsubsection{Composition of Operating Income}

Table 4. 2015-2019 and the First Three Quarters of 2020 Midea Group's Operating Income Composition (By Product)

unit: RMB million

\begin{tabular}{|c|c|c|c|c|c|c|}
\hline Year & $2020-09-30$ & 2019-12-31 & 2018-12-31 & 2017-12-31 & $2016-12-31$ & 2015-12-31 \\
\hline Total Operating Income & $217,753.15$ & $279,380.51$ & $261,819.64$ & $241,918.90$ & $159,841.70$ & $139,347.12$ \\
\hline HVAC & - & $119,607.38$ & $109,394.65$ & $95,352.45$ & - & - \\
\hline Consumer Appliances & - & $109,486.79$ & $102,992.80$ & $98,748.02$ & - & - \\
\hline Robots \& Automation Systems & - & $25,191.96$ & $25,677.92$ & $27,037.06$ & - & - \\
\hline Large Household Appliances & - & - & - & - & $97,855.79$ & $87,932.14$ \\
\hline Small Household Appliances & - & - & - & - & $43,282.93$ & $35,445.86$ \\
\hline Motor & - & - & - & - & $4,127.52$ & $3,533.84$ \\
\hline Logistics & - & - & - & - & $1,907.75$ & $1,652.76$ \\
\hline Other Main Business & - & $2,773.59$ & $2,915.17$ & $2,352.38$ & - & - \\
\hline Other Business & - & $22,320.78$ & $20,839.09$ & $18,428.99$ & $12,667.72$ & $10,782.52$ \\
\hline
\end{tabular}

Table 5. 2015-2019 and the First Three Quarters of 2020 Midea Group's Operating Income Composition (By Region)

unit: RMB million

\begin{tabular}{lcccccc}
\hline \multicolumn{1}{c}{ Year } & $2020-09-30$ & $2019-12-31$ & $2018-12-31$ & $2017-12-31$ & $2016-12-31$ & $2015-12-31$ \\
\hline Total operating income & $217,753.15$ & $279,380.51$ & $261,819.64$ & $241,918.90$ & $159,841.70$ & $139,347.12$ \\
China Mainland & - & $161,432.31$ & $149,257.31$ & $136,756.27$ & $83,162.17$ & $79,147.26$ \\
Foreign & - & $116,783.70$ & $110,407.51$ & $103,956.03$ & $64,011.81$ & $49,417.34$ \\
Other business (region) & - & $1,164.49$ & $2,154.82$ & $1,206.60$ & $12,667.72$ & $10,782.52$ \\
\hline
\end{tabular}


Since Midea Group did not disclose the composition of operating income in detail in the quarterly report, and the statistical caliber of product classification was adjusted in the 2017 annual report, hence some figures are missing. From Table 4 and Table 5, it can be seen that Midea Group's annual operating income has been increasing year by year. In 2017 , the company entered the field of smart household appliances. Henceforth, its main business has been mainly HVAC, consumer appliances, and smart systems. Consumer appliances mainly include refrigerators, washing machines, kitchen appliances, etc., the proportion of business income is basically stable. The operating income of large and small appliances such as HVAC and consumer appliances has always accounted for more than $80 \%$. In terms of regions, sales are still dominated by mainland China. Since 2016, due to the development of overseas business, the proportion of foreign operating income has remained above $40 \%$.

\subsubsection{2. $\quad$ Market Share}

Table 6. The Offline Market Share of Midea Group's Main Products from 2015 to 2019

\begin{tabular}{lccccc}
\hline \multicolumn{1}{c}{ Year } & $2019-12-31$ & $2018-12-31$ & $2017-12-31$ & $2016-12-31$ & $2015-12-31$ \\
\hline Household Air Conditioning & 28.90 & 25 & 24.60 & 23.90 & 25.20 \\
Washing Machine & 27.40 & 26 & 24.60 & 23.00 & 21.30 \\
Refrigerator & 12.60 & 11 & 10.70 & 10.50 & 9.60 \\
Rice Cooker & 43.90 & 43 & 44.80 & 42.20 & 42.30 \\
\hline
\end{tabular}

Table 7. The Online Market Share of Midea Group's Main Products from 2017 to 2019

unit: in percentages

\begin{tabular}{|c|c|c|c|}
\hline Year & 2019-12-31 & $2018-12-31$ & $2017-12-31$ \\
\hline \multirow[t]{2}{*}{ Household Air Conditioning } & 30.00 & & \\
\hline & & 23.30 & 24 \\
\hline Central Air Conditioning & 50.00 & & \\
\hline Washing Machine (Midea Series) & 31.20 & 31.00 & 29 \\
\hline Refrigerator & 17.70 & 16.40 & 15 \\
\hline Rice Cooker & 29.60 & 31.80 & 33 \\
\hline
\end{tabular}

source: aoweiyun(AVC) data

Since Midea Group's main business is mainly HVAC and consumer appliances, it has a rich variety of large and small household appliances and a wide range of products. The statistical calibers of market share in each year are slightly different. Therefore, this paper selects air conditioners and some major household appliances to analyze the market share in the industry. Table 6 and Table 7 respectively present the offline and online market share of Midea Group's four main products in recent years. They show that the offline and online market share of air-conditioning products expanded rapidly one year after the completion of the merger, especially the online sales share of central air-conditioning reached $50 \%$. The offline and online sales share of washing machines and refrigerators has increased slightly every year. Although the acquired party, Little Swan, has leading technology in the washing machine field, the acquisition did not significantly drive Midea Group's market share in the washing machine field. As far as small kitchen appliances are concerned, the offline sales share of rice cookers has always been higher than $40 \%$, but the online sales share has been decreasing year by year. Therefore, firms should take advantage of synergies generated by the integration of resources, expansion of sales channels, and 
enhancement of brand influence after mergers and acquisitions, and should pay attention to the sales model of washing machines and other products.

\subsection{Profitability}

Table 8. Midea Group's Profitability Indicators for Each Year from 2015 to 2019 and the First Three Quarters of 2020

unit: in percentages

\begin{tabular}{|c|c|c|c|c|c|c|}
\hline Year & $2020-09-30$ & $2019-12-31$ & 2018-12-31 & $2017-12-31$ & $2016-12-31$ & 2015-12-31 \\
\hline ROE & 20.53 & 26.21 & 25.80 & 25.63 & 26.62 & 28.66 \\
\hline ROA & 7.51 & 9.55 & 9.50 & 10.35 & 12.21 & 12.63 \\
\hline Gross Profit Margin & 25.29 & 28.86 & 27.54 & 25.03 & 27.31 & 25.84 \\
\hline
\end{tabular}

Note: gross profit margin = gross profit / operating income

The ROE of the company has continued to decline since 2015. In 2017, the company expanded its capital, increased debt financing, and exerted financial leverage. Henceforth, because of the steady growth of net profit, the ROE has rebounded in the year of the merger and after the completion of the merger, but the overall stability was around $26 \%$. By the end of the third quarter of 2020, the net profit has not exceeded the full year of 2019 , but the scale of equity has continued to increase, which has reduced the ROE. Although the company's earnings before interest and tax had increased year by year, the expansion of the assets scale has led to a downward trend in the ROA. Even after mergers and acquisitions, it does not show the improvement in profitability. In terms of sales gross profit margin, due to the substantial expansion of sales in 2017, the company's operating income increased by $51.35 \%$ year-on-year, while gross profit only increased by $38.74 \%$ year-onyear, resulting in a decrease in sales gross margin. Although the growth rate of gross profit in the year of the merger and the one year after the completion of the merger is greater than that of operating income, the growth rate of gross profit and operating income is decreasing year by year. The impact of scale expansion on the marginal return of commodities should be considered. In summary, mergers and acquisitions have little impact on the profitability of enterprises, but the ability of enterprises to use existing resources to create value needs to be taken seriously.

\subsection{Capital Structure and Solvency}

Table 9. Midea Group's Capital Structure and Solvency Indicators at the End of Each Year from 2015 to 2019 and the End of the Third Quarter of 2020

\begin{tabular}{lcccccc}
\hline \multicolumn{1}{c}{ Year } & $2020-09-30$ & $2019-12-31$ & $2018-12-31$ & $2017-12-31$ & $2016-12-31$ & $2015-12-31$ \\
\hline Asset-liability Ratio (\%) & 65.72 & 64.40 & 64.94 & 66.58 & 59.57 & 56.51 \\
Current Ratio & 1.33 & 1.50 & 1.40 & 1.43 & 1.35 & 1.30 \\
Quick Ratio & 1.20 & 1.28 & 1.18 & 1.18 & 1.18 & 1.15 \\
Cash Ratio & 0.41 & 0.53 & 0.31 & 0.50 & 0.28 & 0.34 \\
\hline
\end{tabular}

Note: Asset-liability ratio $=$ total liabilities/total assets Current ratio $=$ current assets/current liabilities

Quick ratio = quick assets (current assets minus poorly realizable and unstable inventories, prepayments, noncurrent assets and other current assets due within one year, etc.)/current liabilities

Cash ratio $=($ monetary funds + marketable securities $) /$ current liabilities 
The asset-liability ratio remained at around $65 \%$ at the end of 2017-2019 and the end of the third quarter of 2020, which was not greatly affected by mergers and acquisitions. On the one hand, the proportion of debt financing is relatively stable, which can play a role of financial leverage. On the other hand, the slightly higher asset-liability ratio increases the debt repayment risk. One year after the completion of mergers and acquisitions, due to the high efficiency of account receivable recovery, monetary funds accounted for a relatively large proportion, and the current ratio, quick ratio and cash ratio increased significantly. The shortterm solvency of the company has improved. At the end of the third quarter of 2020, due to the increase in the proportion of corporate short-term borrowings, all three solvency indicators reduced, but the quick ratio is still higher than before the merger, and the cash ratio is higher than other time nodes except the end of 2017. The proportion of corporate debt financing through noncurrent liabilities of 2017 is higher than that of other years, and the decrease in the proportion of inventory is the main reason for the decrease in the current ratio. Therefore, mergers and acquisitions have a positive impact on the solvency of enterprises.

\section{CONCLUSIONS}

\subsection{Summary}

This paper takes Midea Group's absorption and merger of Little Swan through share swaps as an analysis case, and analyzes the financial performance of public firms in the household appliance industry before and after mergers and acquisitions based on accounting research methods. This paper collects the traditional financial indicators of the public firm in the last five years and one quarter, and examines performance in terms of financial status, profitability, capital structure and solvency. From the perspective of financial status, Midea Group's assets and sales scale have been expanding year by year, and there are few idle funds because of active investing and financing activities. Although the main products have a relatively high market share, they have not taken full advantage of the acquired company, Little Swan, in the washing machine field. Mergers and acquisitions have little impact on the profitability of companies. Since the year of mergers and acquisitions, the increase in gross profit has decreased, and the impact of scale expansion on the marginal returns of commodities can be considered. From the perspective of current ratio, quick ratio, and cash ratio, mergers and acquisitions have a positive impact on the company's solvency.

\subsection{Recommendations}

Midea Group has a good momentum of development and has a continuous expansion trend, especially in 2017. Before the absorption and merger through share swaps,
Little Swan had obvious competitive advantages in the washing machine field. Midea Group intended to fully integrate the internal resources of the washing machine sector through mergers and acquisitions. However, this merger did not significantly drive Midea Group's market share in the washing machine field, and may have a negative impact on the marginal revenue of products due to scale expansion, and the company's ability to use existing resources to generate income weakened. In addition, Midea Group intended to enhance its brand effect through mergers and acquisitions, but mergers and acquisitions did not further expand the company's sales channels, and sales resources were not effectively used. However, the merger and acquisition of share swaps strengthened corporate solvency. Since this paper focuses on a single M\&A case in the household appliance industry, the conclusions drawn are different from those of Zeng and Cao (2020) (based on the furniture manufacturing industry) and Liu (2020) (based on the pharmaceutical industry). Therefore, companies should formulate business strategies according to industry characteristics and development goals. After the completion of mergers and acquisitions, companies should pay attention to the impact of resource integration, scale effect, brand effect and sales channels, and ultimately take advantage of mergers and acquisitions to achieve enterprise development goals.

\section{REFERENCES}

[1] Capron L. The Long-Term Performance of Horizontal Acquisitions [J]. Strategic Management Journal, 1999, 20(11): 987-1018.

[2] Maksimovic V, Phillips G, Yang L. Private and Public Merger Waves[J]. The Journal of Finance, 2013, 68(5): 2177-2216.

[3] Arikan A M, Stulz R M. Corporate Acquisitions, Diversification, and the Firm's Life Cycle[J]. The Journal of Finance, 2016, 71(1):139-194.

[4] You Yanhua. Research on the Motivation and Strategy of Corporate Mergers and Acquisitions[J]. China Business Forum, 2019(16):156-158.

[5] Zhao Zhengchun. Research on the Motivation and Performance of Overseas Mergers and Acquisitions in China's Household Appliance Industry[J]. Industrial Innovation Research, 2020(18): 95-96.

[6] Cai Yue. Analysis of the Motivation and Impact of Corporate Mergers and Acquisitions: Taking Group A's Merger and Acquisition of Company B as an Example [J]. Guangxi Quality Supervision Herald, 2020 (10): 106-107.

[7] Feng Genfu, Wu Linjiang. An Empirical Study on the M\&A Performance of Listed Companies in China [J]. Economic Research, 2001(1): 54-61. 
[8] Zhang Xin. Whether M\&A and Restructuring Create Value-Theoretical and Empirical Research on China's Securities Market[J]. Economic Research, 2003(6): 20-29.

[9] Liu Lingyu, Wang Peng. The Influence of Mergers and Acquisitions Models on the Performance of Listed Companies' Mergers and Acquisitions[J]. China Business Forum, 2020(15): 69-71.

[10] Zeng Jiejie, Cao Hao. Is There a "Winner's Curse" in Furniture Manufacturing Mergers and Acquisitions? Based on the Measurement Evidence of Typical Horizontal Mergers and Acquisitions [J]. World Forestry Research, 2020.

[11] Liu Lijun. Ways to Improve the Financial Performance of Reorganized Pharmaceutical Companies: Taking Company A as an Example [J]. China Economic and Trade Guide, 2020(26): 134136. 